\title{
Improvement of summer tomato (Lycopersicon esculentum Mill.) production using 4-chlorophenoxy acetic acid
}

\author{
Md. Rezaul. Karim ${ }^{a}$,Most. Altaf-Un-Nahar ${ }^{b}$ and Md. Sazzad Sahariar ${ }^{a}$ \\ ${ }^{a}$ Dept. of Horticulture, Bangladesh Agricultural University, Mymensingh \\ ${ }^{b}$ Dept. of Biotechnology, EXIM Bank Agricultural University, Chapai Nawabganj, Bangladesh
}

\begin{abstract}
A field experiment was conducted at the Horticulture Farm in the Department of Horticulture, Bangladesh Agricultural University, Mymensingh to evaluate the influence of different levels of 4chlorophenoxy acetic acid on growth and yield potential of tomato during summer. The twofactor experiment viz., Factor A: four different concentrations of 4-chlorophenoxy acetic acid (4CPA) i.e., concentrations of 4-CPA were (i) 0 ppm (without 4-CPA), (ii) 20 ppm, (iii) 40 ppm and (iv) 60 ppm; and Factor B: two varieties of summer tomato namely, BARI Hybrid Tomato-4 and 8. The experiment was laid out in randomized complete block design with three replications. At harvest, the tallest plant (78.53 cm), number of flowers and fruits (35.11and 18.10, respectively) plant ${ }^{-1}$, fruit yield plant ${ }^{-1}$ and $\mathrm{ha}^{1}$ (1.12 kg and 21.98 tons, respectively) were found in BARI Hybrid Tomato-8. At harvest, the maximum plant height $(85.57 \mathrm{~cm})$, number of flowers and fruits $(44.89$ and 24.97, respectively) plant ${ }^{-1}$, fruit yield and $\mathrm{ha}^{-1}$ (1.32 $\mathrm{kg}$ and 27.78 tons, respectively) were found when 4-CPA applied at 60 ppm, whereas the minimum for these characters were recorded from control plants. In case of combined effect of variety and plant growth regulator, the maximum plant height $(88.90 \mathrm{~cm})$, number of flowers and fruits (40.04 and 21.99, respectively), fruit yield plant ${ }^{-1}$ and $\mathrm{ha}^{-1}$ (1.34 $\mathrm{kg}$ and 28.28 tons, respectively) were observed in BARI Hybrid Tomato-8 when treated with 4-CPA at 60 ppm, and the minimum for all these characters were found in control plants. The results of the present study suggest that 4-CAP at 60 ppm can be practiced for increasing summer tomato production for both the varieties.
\end{abstract}

Key words: Plant growth regulators, growth, fruit set, yield and summer tomato

Please cite this article as: Karim, M. R., Nahar, M. A. \& Sahariar, M. S. (2015). Improvement of summer tomato (Lycopersicon esculentum Mill.) production using 4-chlorophenoxy acetic acid. Journal of Bioscience and Agriculture Research 04(02), 86-91.

This article is distributed under terms of a Creative Common Attribution 4.0 International License.

\section{Introduction}

Tomato (Lycopersicon esculentum Mill.) is one among the foremost vital and widespread vegetable crops in Bangladesh and usually is grown from November to March (cool season; Rahman et. al., 1998) It is cultivated all over the country; however, the yield is very low in the summer-rainy season (from 
April to October). The maximum temperature in summer reaches $34-38^{\circ} \mathrm{C}^{1 *}$ and causes very poor fruit set. Due to the excellent nutritional and processing potentials of tomato, the demand of tomato remains higher round the year, but production is far below the demand, especially in the summer season. Most recently, Bangladesh Agricultural Research Institute (BARI) released tomato varieties, for example, BARI Hybrid Tomato-3, 4, 8 which are suitable for growing in summer season, but their improved production technology has not yet been established. Therefore, it is urgent to explore the heat tolerant tomato varieties with improved production technology that will ensure higher yield under high temperature.

Tomato fruit set is hampered at high temperature, for example, when day and night temperatures exceed above $32^{\circ} \mathrm{C} 21^{\circ} \mathrm{C}$, respectively, due to abnormal stamen development and pollen dehiscence (Sasaki et. al., 2005). As a consequence, efficient tomato production in Bangladesh is mainly confined during winter (November-March) season. At higher temperature, the probability of floral abscission is high after anthesis (Iwahori, 1967). In Bangladesh, the temperature during summer remains high both in the day and at the night which affect fruit-set of tomatoes. Fruit set depends on the successful completion of pollination and fertilization (Gillaspy et al., 1993). Although the influence of plant growth regulators (PGRs), such as auxin and gibberellin, over fruit development already acknowledged back in the early $20^{\text {th }}$ century (Gustafson, 1936, 1939; Witter et al., 1957). In summer, tomato fruit set can be increased by applying plant growth regulators (Hossain et al., 1999; Sasaki et. al., 2005; Khan et. al., 2006; Gemici et. al., 2006; Serrani et. al., 2007; Batlang, 2008; Rahman et al. 2015).

The use of plant growth regulators improved the production of many horticultural crops including tomato which attracts the researchers and growers for its commercial application for summer tomato production. But very limited research has been conducted in respect of type and concentration of PGRs needs to be used to improve the yield and quality of summer tomato. 4-chlorophenoxy acetic acid (4CPA) is an important PGR which increased fruit set and yield of tomato at high temperature (Sasaki et. al., 2005). However, no research has been conducted on the effect of different concentrations of 4-CPA on fruit set and yield of heat tolerant tomato varieties released by BARI. Therefore, the study was undertaken to check the impact of 4-CPA on growth, fruit set and yield of summer tomato released by BARI.

\section{Materials and Methods}

The experiment was carried out at the Horticultural Farm of Horticulture Department, Bangladesh Agricultural University, Mymensingh during June 2014 to October 2014. Two-factor experiment consisted of four different levels of 4-chlorophenoxy acetic acid (4-CPA) i.e., $\mathrm{T}_{0}=$ control (without 4$\mathrm{CPA}$ ), $\mathrm{T}_{1}=4$-CPA @ 20 ppm, $\mathrm{T}_{2}=4$-CPA @ 40 ppm and $\mathrm{T}_{3}=4$-CPA @ 60 ppm; and two varieties of summer tomato namely, BARI Hybrid Tomato- 4 and 8 were used in this study. The experiment was laid out in a randomized complete block design with three replications. Tomato seeds of BARI Hybrid Tomato-4 and 8 were collected from Vegetable Research Division of Bangladesh Agricultural Institute, Joydevpur, Gazipur. Thirty-day-old seedlings were transplanted at a spacing of $60 \mathrm{~cm} \times 50 \mathrm{~cm}$. Manures and fertilizers were applied at the rate of cowdung $12 \mathrm{t} / \mathrm{ha}$, urea $450 \mathrm{~kg} / \mathrm{ha}$, Triple Super Phosphate (TSP) $350 \mathrm{~kg} / \mathrm{ha}$ and Muriate of Potash (MoP) $300 \mathrm{~kg} / \mathrm{ha}$ (BARC, 2012). 4-CPA was sprayed early in the morning to avoid rapid drying of the spray solution due to evaporation. Data were collected from five randomly selected plants from each plot and were statistically analyzed to find out the statistical significance of the experimental results. The means for all the treatments were calculated and the analyses of variance for all the characters were performed by $F$ test. The significance of difference between the pairs of means was separated by LSD test at $5 \%$ or at $1 \%$ levels of probability (Gomez and Gomez, 1984).

\footnotetext{
${ }^{1}$ http://www.weatheronline.co.uk/reports/climate/Bangladesh.htm
} 


\section{Results and Discussion}

\section{Plant height}

Plant height of two varieties showed a statistically significant variation at harvest. BARI Hybrid Tomato-8 produced the taller $(78.53 \mathrm{~cm})$ plants than BARI Hybrid Tomato-4 $(75.30 \mathrm{~cm}$; Table 01). Plant height at harvest was significantly affected by the different concentration of 4-chlorophenoxy acetic acid (4-CPA) (Table 02). The maximum plant height $(85.57 \mathrm{~cm})$ was produced by the application of 4-CPA at the rate of $60 \mathrm{ppm}$, whereas the control treatment produced plants with shorter height $(62.89 \mathrm{~cm})$. Significant influence was found in plant height due to the combined effect of tomato variety and different concentrations of 4-CPA (Table 03). The highest plant height $(88.90 \mathrm{~cm})$ was measured in $\mathrm{V}_{2} \mathrm{~T}_{3}$ whereas $\mathrm{V}_{1} \mathrm{~T}_{0}$ showed the lowest $(62.10 \mathrm{~cm})$ plant height. This might be due to the effect of plant growth regulators on the vegetative part of the plant. Phookhan et. al. (1990) reported that when tomato grown in summer under plastic house conditions, the plant height ranged from $46.00 \mathrm{~cm}$ to $95.00 \mathrm{~cm}$ in an experiment with 29 hybrids of tomato and also showed variations among the hybrids in plant height.

\section{Days required for $\mathbf{5 0 \%}$ flowering}

Significant variation was observed between two varieties in case of days required for flowering (Table 01). The maximum (43.86 days) required to $50 \%$ flowering by BARI Hybrid Tomato- 4 which is more than BARI Hybrid Tomato-8 (41.93 days). Days to 50\% flowering was decreased with the increasing of 4-CPA concentrations. The maximum time to $50 \%$ flowering was observed in $\mathrm{T}_{0}$ treatment ( 44.23 days), whereas the minimum time (41.42 days) was observed with $\mathrm{T}_{3}$ treatment (Table 02). The interaction effect of variety and different concentrations of 4-CPA was highly significant (Table 03). The maximum (45.10 days) time was required in treatment combination of $\mathrm{V}_{1} \mathrm{~T}_{0}$ and the minimum (40.36 days) time was needed to $50 \%$ flowering in treatment combination of $\mathrm{V}_{2} \mathrm{~T}_{3}$ (Table 03).

Table 01. Main effect of variety on growth, fruit set and yield of summer tomatox

\begin{tabular}{|c|c|c|c|c|c|c|c|}
\hline Variety & $\begin{array}{c}\text { Plant height } \\
(\mathrm{cm}) \text { at } \\
\text { harvest }\end{array}$ & $\begin{array}{c}\text { Days required } \\
\text { to } 50 \% \\
\text { flowering } \\
\end{array}$ & $\begin{array}{l}\text { Number } \\
\text { of flowers } \\
\text { plant }^{-1}\end{array}$ & $\begin{array}{l}\text { Number } \\
\text { of fruits } \\
\text { plant }{ }^{-1}\end{array}$ & $\begin{array}{c}\% \\
\text { fruit } \\
\text { set } \\
\end{array}$ & $\begin{array}{l}\text { Fruit yield } \\
\text { (kg) plant }{ }^{-1}\end{array}$ & $\begin{array}{l}\text { Fruit } \\
\text { yield } \\
\text { (t/ha) }\end{array}$ \\
\hline $\mathrm{V}_{1}$ & 75.30 & 43.86 & 32.51 & 16.33 & 50.23 & 1.04 & 20.87 \\
\hline$V_{2}$ & 78.53 & 41.93 & 35.11 & 18.10 & 51.56 & 1.12 & 21.98 \\
\hline $\operatorname{LSD}(0.01)$ & 0.270 & 0.094 & 0.550 & 0.251 & 0.43 & 0.038 & 0.430 \\
\hline $\begin{array}{c}\text { Level of } \\
\text { significance }\end{array}$ & $* *$ & ** & ** & ** & ** & ** & ** \\
\hline
\end{tabular}

\section{Number of flowers per plant}

The number of flowers per plant is an important character which has the importance to determine the yield of tomato. Significant variation was observed between two varieties in case of number of flowers per plant. The highest number of flowers (35.11) per plant was observed in BARI Hybrid Tomato-8 whereas the minimum number of flowers (32.51) per plant was found in BARI Hybrid Tomato-4 (Table 01). There was significant variation in respect of the number of flowers per plant due to the application of different doses of 4-CPA (Table 02). The maximum number of flowers (44.89) per plant was found in $\mathrm{T}_{3}$ treatment i.e. plant treated with 4-CPA at $60 \mathrm{ppm}$. The minimum number of flowers (21.53) per plant was found in the control treatment. There was no significant difference among the treatments and variety combination in respect of number of flowers per plant (Table 03). However, the maximum number of flowers (42.72) per plant was observed in treatment combination of $\mathrm{V}_{1} \mathrm{~T}_{2}$ and the minimum (19.82) was found in treatment combination of $\mathrm{V}_{1} \mathrm{~T}_{0}$. The production of flowers per plant may be affected by the cultivars and temperature. Aung (1976) reported that an extent of decreased flower number depends on cultivars. 


\section{Number of fruits per plant}

Significant variation was found on number of fruits per plant between two tomato varieties (Table 01). The maximum (18.10) fruits were produced in BARI Hybrid Toamto-8 which was statistically different from BARI Hybrid Tomato-4 (16.33). Application of 4-CPA at different concentrations significantly influenced the number of fruits per plant (Table 02). The highest number of fruits (24.97) produced by the $\mathrm{T}_{3}$ treatment and the minimum (9.10) from $\mathrm{T}_{0}$ treatment. The combined effect on the number of fruits per plant was significantly different (Table 03). The treatment with $\mathrm{V}_{2} \mathrm{~T}_{3}$ gave the highest (21.99) number of fruits per plant, whereas the minimum (8.78) fruits was obtained from $V_{1} T_{0}$.

Results of the study showed that application of 4-CPA induced the higher number of fruit set to some extent. In Bangladesh, cultivation of tomato during summer causes low fruit set. Research reports showed that application of plant growth regulators increased fruit set of summer tomato (Hossain et. al., 1999; Rahaman et. al., 1998; Rahman et. al., 2015). It has been reported that in an experiment with $20 F_{1}$ crosses, application of 4-CPA had a noticeable effect on the number and weight of fruits of all lines (AVRDC, 1982). High temperature treatment decreases the levels of auxin and gibberellins like substance, especially in floral buds and developing fruits of tomato (Gustafson, 1936, 1939; Witter et. al., 1957). Therefore, depletion of auxin and gibberellins might cause the low fruit set under high temperature. Then it is speculated that the treatments with 4-CPA reduced the effect of high temperature. Thus, application of 4-CPA under high temperature would have a role in higher fruit set of tomato.

Table 02. Main effect of different concentration of 4-CPA on growth, yield contributing characters and yield of summer tomato ${ }^{x}$

\begin{tabular}{cccccccc}
\hline Treatment & $\begin{array}{c}\text { Plant height } \\
(\mathrm{cm}) \text { at } \\
\text { harvest }\end{array}$ & $\begin{array}{c}\text { Days required } \\
\text { to } 50 \% \\
\text { flowering }\end{array}$ & $\begin{array}{c}\text { Number } \\
\text { of flowers } \\
\text { plant }-1\end{array}$ & $\begin{array}{c}\text { Number } \\
\text { of fruits }_{\text {plant }}^{-1}\end{array}$ & $\begin{array}{c}\% \text { fruit } \\
\text { set } \\
\text { plant }^{-1}\end{array}$ & $\begin{array}{c}\text { Fruit } \\
\text { yield }(\mathrm{kg}) \\
\text { plant }^{-1}\end{array}$ & $\begin{array}{c}\text { Fruit } \\
\text { yield } \\
\text { (t/ha) }\end{array}$ \\
\hline $\mathrm{T}_{0}$ & 62.89 & 44.23 & 21.53 & 9.10 & 42.27 & 0.66 & 12.53 \\
$\mathrm{~T}_{1}$ & 76.85 & 43.56 & 34.76 & 18.43 & 53.02 & 1.10 & 24.48 \\
$\mathrm{~T}_{2}$ & 83.60 & 42.38 & 38.61 & 20.91 & 54.15 & 1.25 & 25.64 \\
$\mathrm{~T}_{3}$ & 85.57 & 41.42 & 44.89 & 24.97 & 55.62 & 1.32 & 27.78 \\
\hline LSD (0.01) & 0.377 & 0.133 & 0.763 & 0.334 & 2.56 & 0.054 & 0.548 \\
\hline $\begin{array}{l}\text { Level of } \\
\text { significance }\end{array}$ & $* *$ & $* *$ & $* *$ & $* *$ & $* *$ & $* *$ \\
\hline
\end{tabular}

\section{Percentage of fruit set per plant}

Significant variation was observed between two varieties in case of percent of fruit set per plant. The maximum of fruit set (51.56\%) per plant was observed in BARI Hybrid Tomato-8), whereas the minimum fruit set $(50.23 \%)$ per plant was found in BARI Hybrid Tomato-4 (Table 01). There was significant variation in respect of percent of fruit set per plant was recorded due to the application of different doses of 4-CPA (Table 02). The maximum number of fruit set (55.62\%) per plant was found in $\mathrm{T}_{3}$ treatment i.e. plant treated with $4-\mathrm{CPA}$ at $60 \mathrm{ppm}$. The minimum number of fruit set (42.27) per plant was found in the control treatment. The combined effect on the percent fruit set per plant was significantly different (Table 03). The maximum fruit set $(54.92 \%)$ per plant was observed in treatment combination of $\mathrm{V}_{2} \mathrm{~T}_{3}$ and the minimum (44.30\%) was found in treatment combination of $\mathrm{V}_{1} \mathrm{~T}_{0}$.

\section{Fruit yield per plant}

There was a significant effect of two varieties on fruit yield per plant which ranged from 1.04 to 1.12 $\mathrm{kg}$ per plant (Table 01). The higher fruit yield $(1.12 \mathrm{~kg}$ ) was obtained in BARI Hybrid Tomato-8 which was statistically different from BARI Hybrid Tomato-4 $(1.04 \mathrm{~kg})$. It was revealed that different concentrations of 4-CPA had a great effect on the fruit yield per plant. The concentration of 4-CPA @ $60 \mathrm{ppm}$ provided significantly higher fruit yield $(1.32 \mathrm{~kg})$ per plant over control plants which produced an average $0.66 \mathrm{~kg}$ fruit per plant (Table 02). The second highest (1.25 kg) was obtained due 
to the application of 4-CPA at $50 \mathrm{ppm}$. The combined effect of fruit per plant was significant among the treatment combinations (Table 03). It was observed that the highest fruit yield (1.34 kg) per plant was recorded in $\mathrm{V}_{2} \mathrm{~T}_{3}$ whereas the lowest $(0.64 \mathrm{~kg})$ was obtained in $\mathrm{V}_{1} \mathrm{~T}_{0}$. The second highest $(1.29 \mathrm{~kg})$ was found in $\mathrm{V}_{1} \mathrm{~T}_{3}$ followed by $\mathrm{V}_{2} \mathrm{~T}_{2}(1.27 \mathrm{~kg})$ and $\mathrm{V}_{1} \mathrm{~T}_{2}(1.23 \mathrm{~kg})$, respectively.

Table 03. Interaction effect of variety and different concentration of 4-CPA on growth, yield contributing characters and yield of summer tomato ${ }^{x}$

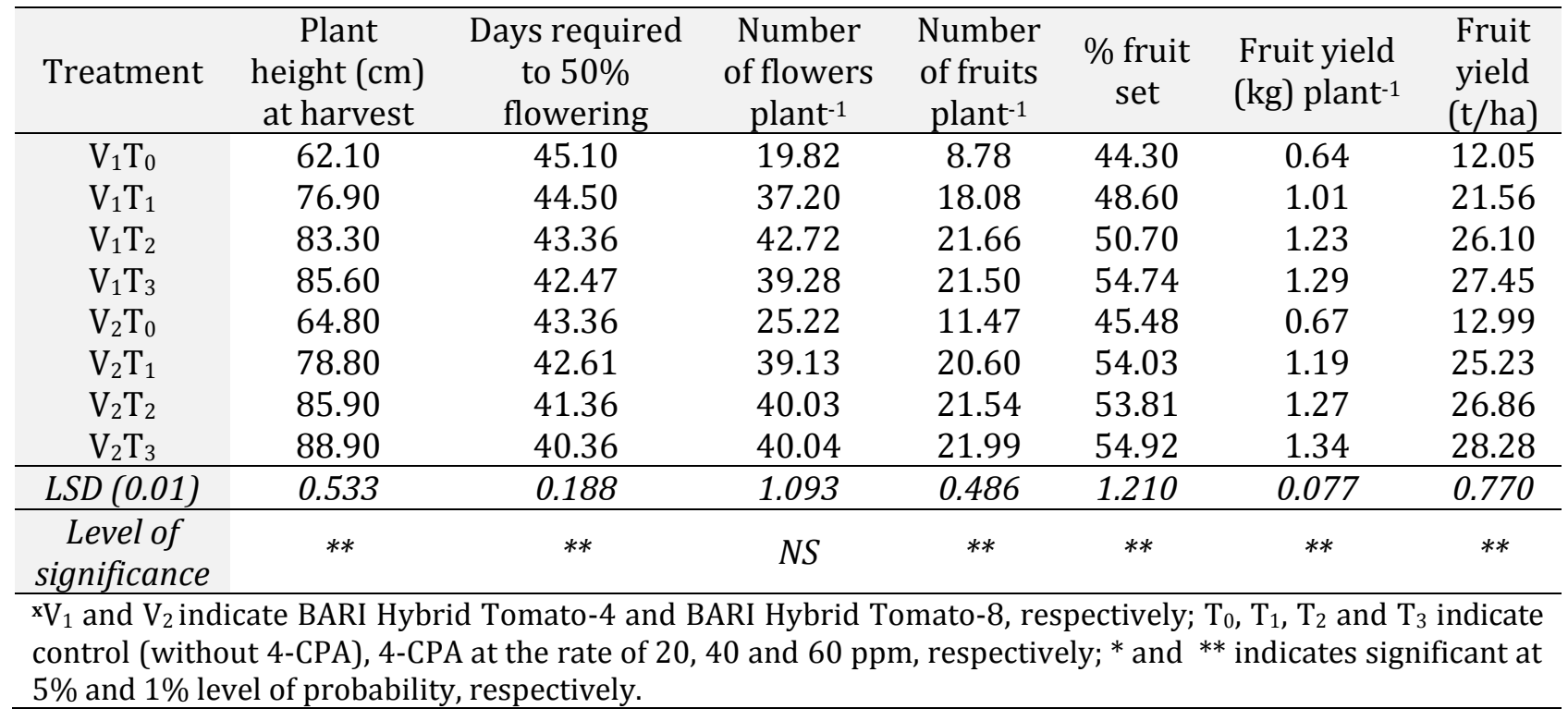

\section{Fruit yield per hectare}

Significant variation was observed between the two summer tomato varieties in respect of yield ( $\mathrm{t}$ ha1). BARI Hybrid Tomato-8 gave higher fruit yield $\left(21.98 \mathrm{t} \mathrm{ha}^{-1}\right)$ and the lowest fruit yield $\left(20.87 \mathrm{t} \mathrm{ha}^{-1}\right)$ was obtained in BARI Hybrid Tomato-4. Different concentrations of 4-CPA significantly influenced fruit yield over control plants (Table 02). The highest fruit yield (27.78 $\left.\mathrm{t} \mathrm{ha}^{-1}\right)$ was obtained from the application of 4-CPA at the rate of $60 \mathrm{ppm}$ and the lowest fruit yield (12.53 tha-1) was found in the control treatment. The second highest (25.64 tha-1) was found in $\mathrm{T}_{2}$ treatment. The combined effect of varieties and different concentration of 4-CPA on the yield of tomato per hectare showed a significant variation (Table 03). It was observed that the highest fruit yield (28.28 t ha-1) was found from the treatment combination of $\mathrm{V}_{2} \mathrm{~T}_{3}$, and $\mathrm{V}_{1} \mathrm{~T}_{3}$ gave the second highest yield (26.86 $\mathrm{t} \mathrm{ha}^{-1}$ ). The lowest yield (12.05 $\mathrm{t} \mathrm{ha}^{-1}$ ) was found from control plants.

\section{Conclusion}

4-chlorophenoxy acetic acid (4-CPA) had a significant influence on growth and yield of tomato. Application of this hormone at $60 \mathrm{ppm}$ gave the highest yield with BARI Hybrid Tomato-8. At the same time, spraying with 4-CPA at $60 \mathrm{ppm}$ performing better for almost all parameters studied for both the varieties i.e. BARI Hybrid Tomato-8 and BARI Hybrid Tomato-4. Therefore, this study provides a strong support that higher concentration of 4-CPA may have more positive effects on the growth and yield of summer tomato. However, it is recommended that similar study can be conducted to see the consequences of upper concentration of 4-CPA on fruit set and yield of tomato with other summer tomato varieties released by BARI and BINA (Bangladesh Agricultural Research Institute and Bangladesh Institute of Nuclear Agriculture, respectively) as well as other agro-ecological zones of the country. In addition, the practice of using synthetic chemicals like 4-CPA should be used only at tested and recommended concentrations to ensure quality products that are safe and healthy for the human health and eco-friendly. 


\section{Acknowledgements}

We thank the Olericulture Division of Bangladesh Agricultural Research Institute (BARI) for providing tomato seeds. The work was partly supported by the Ministry of Science and Technology, Government of the People's Republic of Bangladesh through the Special Allocation for Science and Technology under the project entitled "Development of Improved Production Technology for Summer Tomato in Bangladesh" (2014-2015/BS-29) to M. R. Karim.

\section{References}

[01]. Aung, L. H. (1976). Effect of photoperiod and temperature on vegetable and reproductive responses of Lycopersicon esculentum Mill. J. Amer. Soc. Hort. Sci., 101, 358-360.

[02]. AVRDC. (1982). Progress Report. Asian Vegetables Research and Development Center, Shanhua, Tainan, Taiwan, pp. 19-54.

[03]. BARC, (2012). Fertilizer Recommendation Guide-2012. Bangladesh Agricultural Research Council, Farmgate, Dhaka. pp. 117.

[04]. Batlang, U. (2008). Benzyl adenine plus gibberellins (GA4+7) increase fruit size and yield in greenhouse grown hot pepper (Capsicum annum L.). J. Biol. Sci., 8(3), 659-662.

[05]. Gemici, M., Türkyilmaz, B. \& Tan, K. (2006). Effect of 2,4-D and 4-CPA on yield and quality of the tomato, Lycopersicon esculentum Mill. JFS, 29, 24-32.

[06]. Gillaspy, G., Ben-David, H., \& Gruissem, W. (1993). Fruits: a developmental perspective. The Plant Cell, 5, 1439-1451.

[07]. Gomez, K. A. \& Gomez, A. A. (1984). Statistical Procedures for Agricultural Research. 2nd edn. A Wiley-Inter science Publication. John Wiley and Sons. pp: 28-192.

[08]. Gustafson, F. G. (1936). Inducement of fruit development by growth promoting chemicals. Proceedings of the National Academy of Sciences, USA, 22, 628-636.

[09]. Gustafson, F. G. (1939). The cause of natural parthenocarpy. American Journal of Botany, $26,135-138$.

[10]. Hossain, M. A., Gaffer, M. A., Chowdhury, J. C. S., Rahman, M. S. \& Hossain, M. I. (1999). A study on postharvest practices and loss of tomato in some selected areas of Bangladesh. Bangladesh J. Agril. Res., 24(2), 299.

[11]. Iwahori, S. (1967). Auxin of tomato fruit-set at different stages of its development with a special reference to high temperature injuries. Plant and Cell Physiology, 8, 15-22.

[12]. Khan, M. M. A., Gautam, A. C., Mohammad, F., Siddiqui, M. H., Naeem, M. \& Khan, M. N. (2006). Effect of gibberellic acid spray on performance of tomato. Turk. J. Biol., 30:11-16.

[13]. Phookhan, D. B., Talukdar, P., Shadeque, A. \& Chakravarty, B. K. (1990). Genetic variability and heritability in tomato (Lycopersicon esculentum Mill.) genotypes during summer season under plastic house condition. Indian J. Agric., 68(6), 304-306.

[14]. Rahman, A. K. M. S., Hossain, S.M.M. \& Islam, M. S. (1998). New hybrid tomato for summer season in Bangladesh. HortScience, 33(3), 527.

[15]. Rahman, M., Nahar, M. A., Sahariar, M. S. \& Karim, M. R. (2015). Plant growth regulators promote growth and yield of summer tomato (Lycopersicon esculentum Mill.). Progress. Agric., (accepted).

[16]. Sasaki, H., Yano, T. \& Yamasaki, A. (2005). Reduction of high temperature inhibition in tomato fruit set by plant growth regulators. JARQ, 39, 135-138.

[17]. Serrani, J. C., Sanjua'n, R., Ruiz, R. O., Fos, M. \& Garcı'a-Martı́nez, J. L. (2007). Gibberellin regulation of fruit set and growth in tomato. Plant Physiology, 145, 246-257.

[18]. Witter, S. H., Bukovac, M. J., Sell, M. H. \& Weller, L. E. (1957). Effects of gibberellin on flowering and fruit setting. Plant Physiology, 32: 39-41. 